\title{
Bone regeneration performance of surface-treated porous titanium
}

Citation for published version (APA):

Yavari, S. A., van der Stok, J., Chai, Y. C., Wauthle, R., Birgani, Z. T., Habibovic, P., Mulier, M., Schrooten, J., Weinans, H., \& Zadpoor, A. A. (2014). Bone regeneration performance of surface-treated porous titanium. Biomaterials, 35(24), 6172-6181. https://doi.org/10.1016/j.biomaterials.2014.04.054

Document status and date:

Published: 01/08/2014

DOI:

10.1016/j.biomaterials.2014.04.054

Document Version:

Publisher's PDF, also known as Version of record

Document license:

Taverne

Please check the document version of this publication:

- A submitted manuscript is the version of the article upon submission and before peer-review. There can be important differences between the submitted version and the official published version of record.

People interested in the research are advised to contact the author for the final version of the publication, or visit the DOI to the publisher's website.

- The final author version and the galley proof are versions of the publication after peer review.

- The final published version features the final layout of the paper including the volume, issue and page numbers.

Link to publication

\footnotetext{
General rights Owners
rights.

- You may freely distribute the URL identifying the publication in the public portal. please follow below link for the End User Agreement:

www.umlib.nl/taverne-license

Take down policy

If you believe that this document breaches copyright please contact us at:

repository@maastrichtuniversity.nl

providing details and we will investigate your claim.
}

Copyright and moral rights for the publications made accessible in the public portal are retained by the authors and/or other copyright owners and it is a condition of accessing publications that users recognise and abide by the legal requirements associated with these

- Users may download and print one copy of any publication from the public portal for the purpose of private study or research.

- You may not further distribute the material or use it for any profit-making activity or commercial gain

If the publication is distributed under the terms of Article $25 \mathrm{fa}$ of the Dutch Copyright Act, indicated by the "Taverne" license above, 


\title{
Bone regeneration performance of surface-treated porous titanium
}

\author{
Saber Amin Yavari a,b,*, Johan van der Stok ${ }^{c}$, Yoke Chin Chai ${ }^{\mathrm{d}, \mathrm{e}, \mathrm{f}}$, Ruben Wauthle ${ }^{\mathrm{g}, \mathrm{h}}$, \\ Zeinab Tahmasebi Birgani ${ }^{i}$, Pamela Habibovic ${ }^{\mathrm{i}}$, Michiel Mulier ${ }^{\mathrm{j}}$, Jan Schrooten ${ }^{\mathrm{k}}$, \\ Harrie Weinans ${ }^{\mathrm{a}, \mathrm{c}, 1}$, Amir Abbas Zadpoor ${ }^{\mathrm{a}}$
}

\author{
${ }^{a}$ Faculty of Mechanical, Maritime, and Materials Engineering, Delft University of Technology (TU Delft), Mekelweg 2, 2628 CD Delft, The Netherlands \\ ${ }^{\mathrm{b}}$ FT Innovations BV, Braamsluiper 1, 5831 PW Boxmeer, The Netherlands \\ c Orthopaedic Research Laboratory, Department of Orthopaedic, Erasmus University Rotterdam Medical Centre, Rotterdam, The Netherlands \\ d Prometheus, Division of Skeletal Tissue Engineering, Bus 813, OEN1, Herestraat 49, KU Leuven, 3000 Leuven, Belgium \\ e Tissue Engineering Laboratory, Skeletal Biology and Engineering Research Center, Bus 813, OEN1, Herestraat 49, KU Leuven, 3000 Leuven, Belgium \\ ${ }_{\mathrm{f}}^{\mathrm{f}}$ Department of Biomedical Engineering, Faculty of Engineering, University of Malaya, 50603 Kuala Lumpur, Malaysia \\ ${ }^{g}$ KU Leuven, Department of Mechanical Engineering, Section Production Engineering, Machine Design and Automation (PMA), Celestijnenlaan 300B, \\ 3001 Leuven, Belgium \\ ${ }^{\mathrm{h}}$ LayerWise NV, Grauwmeer 14, 3001 Leuven, Belgium \\ i Department of Tissue Regeneration, MIRA Institute for Biomedical, Technology and Technical Medicine, University of Twente, PO Box 217, 7500AE Enschede, \\ The Netherlands \\ ${ }^{\mathrm{j}}$ Department of Orthopaedic, University Hospitals KU Leuven, UZ Pellenberg, Weligerveld 1, 3212 Lubbeek, Belgium \\ ${ }^{\mathrm{k}}$ Department of Metallurgy and Materials Engineering, KU Leuven, Kasteelpark Arenberg $44-$ PB 2450, B-3001 Heverlee, Belgium \\ ${ }^{1}$ Department of Orthopedics and Dept. Rheumatology, UMC Utrecht, Heidelberglaan100, 3584CX Utrecht, The Netherlands
}

\section{A R T I C L E I N F O}

\section{Article history:}

Received 18 February 2014

Accepted 12 April 2014

Available online 6 May 2014

\section{Keywords}

Bone grafting

Selective laser melting

Nanotopography

Surface chemistry

Bone regeneration

Surface-cell interaction

\begin{abstract}
A B S T R A C T
The large surface area of highly porous titanium structures produced by additive manufacturing can be modified using biofunctionalizing surface treatments to improve the bone regeneration performance of these otherwise bioinert biomaterials. In this longitudinal study, we applied and compared three types of biofunctionalizing surface treatments, namely acid-alkali (AcAl), alkali-acid-heat treatment (AlAcH), and anodizing-heat treatment $(\mathrm{AnH})$. The effects of treatments on apatite forming ability, cell attachment, cell proliferation, osteogenic gene expression, bone regeneration, biomechanical stability, and bone-biomaterial contact were evaluated using apatite forming ability test, cell culture assays, and animal experiments. It was found that $\mathrm{AcAl}$ and $\mathrm{AnH}$ work through completely different routes. While AcAl improved the apatite forming ability of as-manufactured (AsM) specimens, it did not have any positive effect on cell attachment, cell proliferation, and osteogenic gene expression. In contrast, AnH did not improve the apatite forming ability of AsM specimens but showed significantly better cell attachment, cell proliferation, and expression of osteogenic markers. The performance of $\mathrm{AlAcH}$ in terms of apatite forming ability and cell response was in between both extremes of AnH and AsM. AcAl resulted in significantly larger volumes of newly formed bone within the pores of the scaffold as compared to AnH. Interestingly, larger volumes of regenerated bone did not translate into improved biomechanical stability as AnH exhibited significantly better biomechanical stability as compared to AcAl suggesting that the beneficial effects of cell-nanotopography modulations somehow surpassed the benefits of improved apatite forming ability. In conclusion, the applied surface treatments have considerable effects on apatite forming ability, cell attachment, cell proliferation, and bone ingrowth of the studied biomaterials. The relationship between these properties and the bone-implant biomechanics is, however, not trivial.
\end{abstract}

(c) 2014 Elsevier Ltd. All rights reserved.

\footnotetext{
* Corresponding author. Faculty of Mechanical, Maritime, and Materials Engineering, Delft University of Technology (TU Delft), Mekelweg 2, 2628 CD Delft, The Netherlands. Tel.: +31 15 2781859; fax: +31 152784717 .

E-mail addresses: s.aminyavari@tudelft.nl, saber.aminyavari@gmail.com (S. Amin Yavari).
}

\section{Introduction}

In clinical practice, bone is often substituted by biomaterials that fulfill (some of) its functions either temporarily or permanently. Autologous and allogeneic bone has traditionally been the most widely used bone substitutes with autologous iliac crest bone being 
the clinical gold standard [1]. However, there is often limited bone stock available for autologous bone grafting. Moreover, donor-site morbidity and complication rates of around $20 \%$ have been reported for iliac crest and intramedullary canal bone harvesting [2]. Synthetic bone substituting materials are therefore being continuously developed. Synthetic bone substituting biomaterials need to provide enough mechanical support without being overly stiff, and well integrate within the host bony tissue. Increasingly, it is important for bone substitutes to enhance bone regeneration [3] and improve the biomechanical stability of the treated bony defects [4].

In this study, we introduce and evaluate three variations of surface-modified porous titanium alloy biomaterials. Recent developments in additive manufacturing techniques such as selective laser sintering [5-8] and selective laser melting [9-12] have enabled production of highly porous titanium alloy biomaterials with precisely-controlled micro-architectures. One can therefore ensure that the porous structure is fully-interconnected [13], has a precisely-controlled pore size that can be optimized for cell attachment, proliferation, and migration [14], and possesses overall mechanical properties in the range of bone mechanical properties [15]. In addition, the ample pore space allows for incorporation of, for example, hydrogels that release growth factors [16] to maximize the bone regeneration performance of the biomaterial.

Another important feature of highly porous bone substitutes is their large surface area. It is known that titanium alloys are generally bioinert $[17,18]$ and may be also hydrophobic [19]. Hydrophobicity could adversely affect cell attachment [20] while bioinertness means that the bioactivity potential of the highly porous biomaterials remains unused. One may therefore need to use bio-functionalization techniques to improve cell attachment and induce bioactivity on the surface of porous titanium bone substitutes. Since surface chemistry [21,22] and nanotopography [23-27] both play important roles, biofunctionalizing techniques could target both in order to achieve the best performance.

In this study, we used three surface treatment techniques to modify both surface chemistry and topography of highly porous titanium bone substitutes. The aim was to 1 . improve cell attachment and proliferation, 2. induce a hierarchical micro- and nanotopography on the surface of the biomaterial, and 3. improve the osseointegration of the biomaterial through enhanced apatite formation. The surface modifications included two chemical surface treatment techniques, namely alkali-acid-heat treatment [17,2832] and acid-alkali treatment [33-35], and one electrochemical surface treatment technique, namely anodizing [36-39]. The abovementioned surface modifications were chosen, because they are known to induce one or more of the three above-mentioned effects and also because they can be applied on complex 3D surfaces. A comprehensive longitudinal in vitro and in vivo study was performed to evaluate the bone regeneration performance of the applied surface modification techniques and to benchmark the surface modifications techniques against each other.

\section{Materials and methods \\ 2.1. Materials and manufacturing}

Spherical pre-alloyed Ti6Al4V ELI powder (ASTM B348, grade 23) was used for manufacturing porous titanium alloy structures using selective laser melting (Layerwise NV, Belgium) as detailed before [40]. The porous structures were based on dodecahedron unit cells with the following design (nominal) dimensions: strut size $=120 \mu \mathrm{m}$, pore size $=500 \mu \mathrm{m}$, porosity $=88 \%$. The specimens were built on top of a solid titanium alloy substrate in an inert atmosphere and were subsequently removed from the substrate using wire electro-discharge machining (EDM). Diskshaped samples ( $68 \mathrm{~mm} \times \mathrm{L} 3 \mathrm{~mm}$ ) were used for in vitro assays (Fig. 1a). The samples used for in vivo implantation were based on a mid-diaphyseal segment of a rat femur (Fig. 1a). The actual micro-architectures of both as-built and surfacetreated samples were characterized using micro-computed tomography (micro$\mathrm{CT}$ ). The micro-CT images were subsequently segmented using a global threshold for detecting the morphometric details of the titanium structure [40]. The morphometric parameters of the porous structure including pore size, strut size, and the average structure porosity were then determined using the segmented micro-CT images and 3D morphometry algorithms [40].

\subsection{Surface treatments}

For the alkali-acid-heat $(\mathrm{AlAcH})$ treatment [32], the specimens were first immersed in $5 \mathrm{~m} \mathrm{NaOH}$ (Sigma-Aldrich) solution $\left(24 \mathrm{~h}, 60^{\circ} \mathrm{C}\right.$ ) and were subsequently washed gently with distilled water. The specimens were then immersed in hot water $\left(24 \mathrm{~h}, 40^{\circ} \mathrm{C}\right)$ subsequently in $0.5 \mathrm{~mm} \mathrm{HCl}$ (Sigma-Aldrich) $\left(24 \mathrm{~h}, 40^{\circ} \mathrm{C}\right)$. Afterwards, the specimens were dried in an oven $\left(24 \mathrm{~h}, 40^{\circ} \mathrm{C}\right)$. The dried specimens were heated with a rate of $5^{\circ} \mathrm{C} / \mathrm{min}$ to $600^{\circ} \mathrm{C}$ and were kept at that temperature for $1 \mathrm{~h}$ after which they were allowed to cool down in the oven to the room temperature.

For the acid-alkali (AcAl) treatment [35], the specimens were first immersed in a mixture of $18 \% \mathrm{HCl}$ (Sigma-Aldrich) and $48 \% \mathrm{H}_{2} \mathrm{SO}_{4}$ (Sigma-Aldrich) aqueous solutions $\left(1 \mathrm{~h}, 70^{\circ} \mathrm{C}\right)$ followed by immersion in $6 \mathrm{~m} \mathrm{NaOH}$ (Sigma-Aldrich) $(5 \mathrm{~h}$, $70^{\circ} \mathrm{C}$ ). The specimens were afterwards washed with distilled water and dried in an oven $\left(24 \mathrm{~h}, 40^{\circ} \mathrm{C}\right)$.

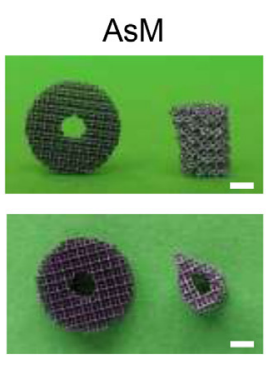

a

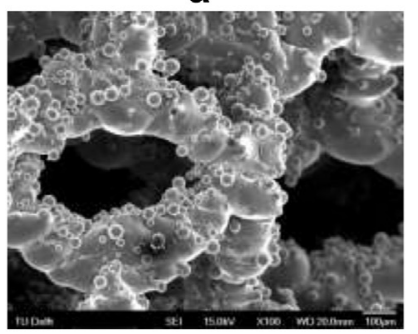

e

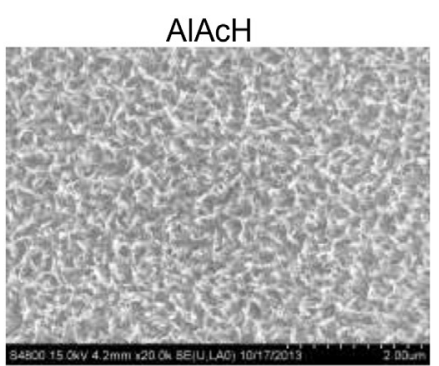

b

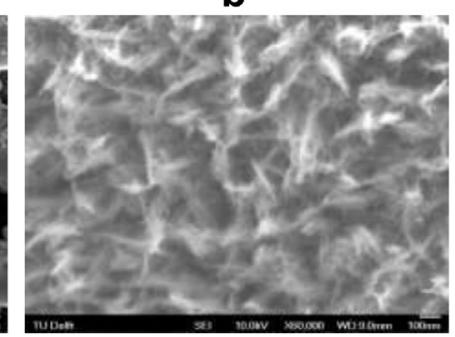

f

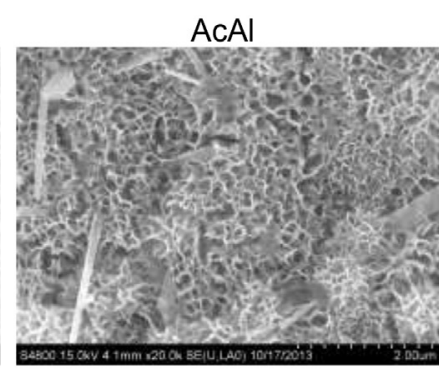

C

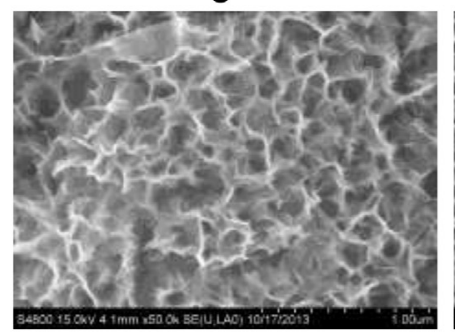

g

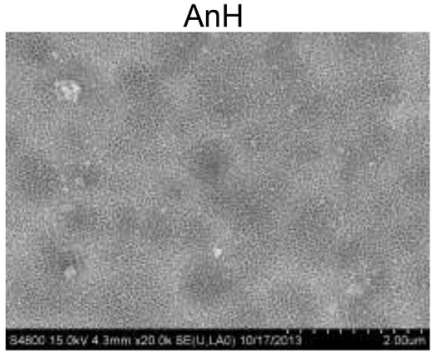

d

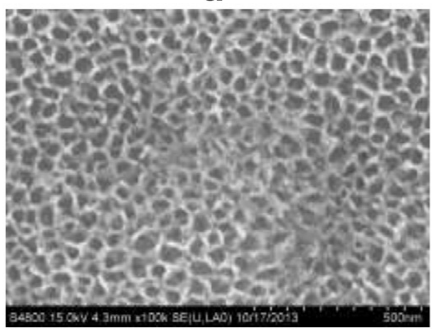

h

Fig. 1. Macrographs of in vitro and in vivo test specimens; scale bar: $2 \mathrm{~mm}$ (a) as well as the SEM pictures of AsM (e), AlAcH (b, f), AcAl (c, g), and AnH (d, h) specimens. 
For the anodizing treatment (An), the pre-existing oxide layer of the specimens was first removed by immersing the specimens for $5 \mathrm{~min}$ in an acidic mixture consisting of $2 \mathrm{~mL} \mathrm{48 \%} \mathrm{HF,} 3 \mathrm{~mL} \mathrm{70 \%} \mathrm{HNO}_{3}$ (both Sigma-Aldrich), and $100 \mathrm{~mL}$ distilled water. The specimens were then treated using an anodizing process optimized for porous titanium structures in a previous study [19]. An inert platinum mesh and the porous titanium structure were respectively cathode and anode. The anode and cathode were connected using copper wires respectively to the positive and negative ports of a 60V/20A power supply (CPX400SP; Aim TTI). The separation distance of anode and cathode in the container, i.e. a Teflon beaker (VWR), was $3 \mathrm{~cm}$. A $0.5 \mathrm{wt} \% \mathrm{HF}$ (Sigma-Aldrich) solution was used as electrolyte. After anodizing, the specimens were heat treated $\left(1 \mathrm{~h}, 500{ }^{\circ} \mathrm{C}, 100 \mathrm{mmHg}\right)$ in an Argon furnace which was heated with a rate of $10{ }^{\circ} \mathrm{C} / \mathrm{min}$ to the annealing temperature and kept at that temperature for the duration of heat treatment. The specimens cooled down in the furnace after it was turned off. To characterize the surface of specimens two scanning electron microscopes (SEM) were employed, namely Hitachi (S-4800 FE-SEM, Japan) and JEOL (JSM-6500F, Japan).

\subsection{Apatite forming ability test}

The apatite forming ability of surface-treated specimens was evaluated by immersing them in a simulated body fluid (SBF). The SBF solution was prepared according to the protocol described by Kokubo and Takadama [41]. In summary, the reagents presented in Table 1 were dissolved one by one in $700 \mathrm{~mL}$ of deionized water at $37{ }^{\circ} \mathrm{C}$. The $\mathrm{pH}$ of the solution was adjusted at 7.4 using $1 \mathrm{M} \mathrm{HCl}$. Deionized water was subsequently added to the solution to reach a volume of $1 \mathrm{~L}$.

The specimens were immersed in $15 \mathrm{~mL}$ fresh SBF using $50 \mathrm{~mL}$ plastic tubes. The tubes were then placed in a shaking water bath at $37^{\circ} \mathrm{C}$. The samples were removed from the water bath after 1,2 , and 4 weeks and washed with deionized water twice and dried overnight in an air oven at $37^{\circ} \mathrm{C}$. An SEM (Philips XL30, Eindhoven, The Netherlands) coupled with an energy dispersive X-ray spectrometer (EDS) (AMETEK Materials Analysis Division, Mahwah, NJ, USA) was used for observing the surface of samples and elemental analysis. Samples were sputtered with a thin layer of gold using a common sputtering instrument (Cressington 108A, Watford, UK) to improve the surface conductivity. The EDS spectra were taken at an accelerating voltage of $10 \mathrm{KeV}$ and working distance of $10 \mathrm{~mm}$.

\subsection{Cell culture assays}

A pool (six donors, age $14.9+2.1$, passage 5 ) of human periosteum-derived cells ( $\mathrm{hPDC}$ ) were thawed from liquid nitrogen cell bank, expanded in T-175 flask, and harvested upon confluent. Cell suspension (i.e. $100 \mu \mathrm{l}$ ) containing 50,000 cells was drop-seeded onto each scaffold and incubated statically for $1 \mathrm{~h}$ to allow cell attachment before being transferred onto a 3D rotator (GrantBio) to perform dynamic rotation seeding for overnight [42]. For cell attachment analysis, the cell seeding efficiency (CSE) was calculated by quantifying the total DNA content of the cell-seeded scaffolds ( $n=3$ ) using Quant-iTTM dsDNA HS assay kit (Invitrogen). For cell proliferation assay, the cell-seeded scaffolds were transferred into 24-well plates and cultured for 21 days in DMEM medium (DMEM-GlutaMax ${ }^{\mathrm{TM}}-1$, Gibco) containing $10 \%$ fetal bovine serum (Gibco), $1 \%$ sodium pyruvate, and $1 \%$ antibiotics/ antimycotics. Then, the metabolic activity (PrestoBlue ${ }^{\circledR}$, Life technologies ${ }^{\mathrm{TM}}$ ) and total DNA content were quantified at defined time points.

At 1,7 , and 21 days of culture, the cell viability on the scaffolds was assessed by staining living cells with Calcein AM and dead cells with Ethidium Homodimer (LIVE/DEAD ${ }^{\circledR}$ cell viability kit, Life technologies ${ }^{\mathrm{TM}}$ ). For cell culture morphology, the samples were fixed with $2.5 \%$ glutaldehyde, post-fixed with osmium tetroxide, dehydrated in gradually increased alcohol concentrations, and chemically dried with hexamethyldisilane. Then, the samples were sputtered with gold-palladium coating and the cell culture morphology was observed with SEM coupled with EDS (FEI XL30 FEG) at $10 \mathrm{kV}$

The effect of surface modifications on osteogenic differentiation of hPDCs was quantified by quantitative, real-time polymerase chain reaction. Briefly, at 1, 7 and 21 days of culture, the samples were harvested in RLT buffer, and the total RNA was extracted using a RNA extraction kit (Qiagen) and subsequently converted into cDNA using cDNA synthesis kit (Fermentas). The expression level of several osteogenic gene markers, namely alkaline phosphatase (ALP), runt-related transcription factor-

\section{Table 1}

The reagents used in preparation of SBF solution.

\begin{tabular}{lllll}
\hline Number & Reagent & Weight $(\mathrm{g})$ & Purity (\%) & Molecular weight \\
\hline 1 & $\mathrm{NaCl}$ & 8.035 & 99.5 & 58.4430 \\
2 & $\mathrm{NaHCO} 3$ & 0.355 & 99.5 & 84.0068 \\
3 & $\mathrm{KCl}$ & 0.225 & 99.5 & 74.5515 \\
4 & $\mathrm{~K} 2 \mathrm{HPO} 4.3 \mathrm{H} 2 \mathrm{O}$ & 0.231 & 99 & 228.2220 \\
5 & $\mathrm{MgCl} 2.6 \mathrm{H} 2 \mathrm{O}$ & 0.311 & 98 & 110.9848 \\
6 & $1.0 \mathrm{M}-\mathrm{HCl}$ & $39 \mathrm{~mL}$ & - & - \\
7 & $\mathrm{CaCl} 2$ & 0.292 & 95 & 142.0428 \\
8 & $\mathrm{Na2SO} 4$ & 0.072 & 99 & 121.1356 \\
9 & $\mathrm{Tris}$ & 6.118 & 99 & 121.1356 \\
\hline
\end{tabular}

2 (Runx2), osteocalcin (OCN), Osterix (Osx), collagen type-1 (Col-1), and vascular endothelial growth factor (VEGF), were quantified using Sybr Green primers in a Rotor-Gene sequence detector at $95^{\circ} \mathrm{C}$ for $3 \mathrm{~min}, 40$ cycles of $95^{\circ} \mathrm{C}$ for $3 \mathrm{~s}$, and $60^{\circ} \mathrm{C}$ for $60 \mathrm{~s}$. Expression levels were calculated based on the 2-dCT method by normalizing values to that of the housekeeping gene $\beta$-actin.

\subsection{Animal experiments}

Critical-size femoral bone defects (length $=6 \mathrm{~mm}$ ) were induced in the middiaphysis of thirty male Wistar rats and were grafted with surface treated porous titanium scaffolds ( $n=10$ per surface treatment). The Animal Ethics Committee of the Erasmus University approved the study and national guidelines for care and use of laboratory animals (Netherlands) were followed. The details of the surgery, presurgery, and post-surgery treatment and care protocols are described elsewhere $[16,43]$. Rats were sacrificed twelve weeks after the surgery with pentobarbital overdose ( $200 \mathrm{mg} / \mathrm{kg}$ body weight). 4,8 , and 12 weeks after surgery, in vivo micro-CT scans (SkyScan 1076 scanner, Bruker micro-CT NV, Kontich, Belgium) were acquired under general anesthesia (1-3.5\% isoflurane) using a $35 \mu \mathrm{m}$ resolution protocol (voltage: $95 \mathrm{kV}$, current: $105 \mu \mathrm{A}, 1.0 \mathrm{~mm} \mathrm{Al} / 0.25 \mathrm{~mm} \mathrm{Cu}$ filter, rotation step: $0.75^{\circ}$, scan time: $14 \mathrm{~min})$. Ex vivo micro-CT scans were acquired after sacrificing the animals using an $18 \mu \mathrm{m}$ resolution protocol (voltage: $95 \mathrm{kV}$, current: $100 \mu \mathrm{A}, 1.0 \mathrm{~mm} \mathrm{Al} /$ $0.25 \mathrm{~mm} \mathrm{Cu}$ filter, rotation step: $0.5^{\circ}$ ). Volumetric reconstruction software NRecon version 1.6.6 (Bruker micro-CT N.V., Kontich, Belgium) was used to reconstruct micro-CT images. Regenerated bone volume (BV) was measured in terms of total volume of bone formed within the bony defect (total BV), bone formed outside the scaffolds (outer BV), bone formed inside the porous space of the scaffolds (porous $\mathrm{BV}$ ), and bone formed in the medullary canal of the scaffold (inner BV). A custommade algorithm within CTAnalyser (ver 1.13, Bruker micro-CT NV, Kontich, Belgium) was employed for calculating BV for the above-mentioned volumes of interest (VOI). The details of the image processing technique were described elsewhere [16,40,43]. DataViewer 1.4 (Bruker micro-CT N.V., Kontich, Belgium) was used for calculating bone bridging on ex vivo scans.

Two specimens from each group were used for histological observations. The harvested specimens were initially immersed in $10 \%$ neutral buffered formalin solution for two days, then dehydrated in graded ethanol solution from 70 to $100 \%$, and finally embedded in methyl methacrylate (MMA). The embedded samples were sliced ( $20 \mu \mathrm{m}$ sections) using a diamond saw (Leica SP1600, Rijswijk, The Netherlands) and stained with $0.3 \%$ basic fuchsin and $1 \%$ methylene blue solutions. Basic fuchsin and methylene blue stain mineralized bone and fibrous tissue respectively red and blue.

\subsection{Biomechanical testing}

For biomechanical testing under torsion, both ends of each femur were embedded in a cold-cured epoxy resin (Technovit 4071, Heraeus Kulzer, Germany). On the upper clamping side, a Cardan joint was used to ensure the specimens were subjected to pure rotation without bending. The lower sides of the specimens were simply fixed. The tests were performed until failure with a rotation rate of $0.5^{\circ} \mathrm{s}^{-1}$ using a static mechanical testing machine (Zwick GmbH, Ulm, Germany). The torsional strength (maximum torque to failure, N.mm) and maximum rotation (degree) were determined and reported.

\subsection{Statistical analysis}

When comparing different groups, one-way ANOVA together with TukeyKramer post-hoc analysis was used to identify significant differences (significance threshold: $p<0.05$ ). Two-way repeated-measures ANOVA with post-hoc analysis was carried out both with and without Bonferroni correction to compare the overal performance of different surface treatments in terms of the bone regeneration measured in different time points, i.e. 4,8 , and 12 weeks.

\section{Results}

\subsection{Surface treatment}

The porosity of the specimens treated with different techniques varied between 85 and 90\% (Table 2). The mean pore and strut sizes

\section{Table 2}

The morphometric parameters of the scaffolds with different types of surface treatments measured using micro-CT scans.

\begin{tabular}{llll}
\hline & AlAcH & AcAl & AnH \\
\hline Segmentation threshold & $100-255$ & $90-255$ & $110-255$ \\
Porosity, $(\%)$ & 85 & 89 & 86 \\
Pore size $(\mu \mathrm{m})$ & $577 \pm 146$ & $596 \pm 145$ & $578 \pm 142$ \\
Strut size $(\mu \mathrm{m})$ & $165 \pm 43$ & $160 \pm 40$ & $175 \pm 50$ \\
\hline
\end{tabular}


Table 3

EDS analysis of the elements found on the surface of surface treated porous titanium bone substitutes.

\begin{tabular}{llllll}
\hline & $\mathrm{O}(\mathrm{wt} \%)$ & $\mathrm{Na}(\mathrm{wt} \%)$ & $\mathrm{Al}(\mathrm{wt} \%)$ & $\mathrm{V}(\mathrm{wt} \%)$ & $\mathrm{Ti}(\mathrm{wt} \%)$ \\
\hline AsM & - & - & 1.68 & 4.80 & 93.52 \\
AlAcH & 35.42 & - & 3.36 & 1.62 & 59.60 \\
AcAl & 36.07 & 11.20 & 2.48 & 1.88 & 48.38 \\
AnH & 29.98 & & 3.76 & 2.94 & 63.31 \\
\hline
\end{tabular}

were not significantly different among the surface treatments and were respectively $575-600 \mu \mathrm{m}$ and $160-175 \mu \mathrm{m}$. While AsM surfaces were relatively featureless with some loosely attached powder particles (Fig. 1e), the modified surfaces all possessed nanotopographical features and modified surface chemistry (Fig. 1b-d, Tables 3,4). As for AlAcH, the modified surface exhibited irregular nano-scale features in the range of 100-200 nm (Fig. 1b, f). EDS analysis identified oxygen on AlAcH surfaces implying the presence of titanium oxide layer (Table 3). For the AcAl treatment, the features appearing on the surface were irregular as well and in the same range as in $\mathrm{AlAcH}$ surfaces (Fig. 1c, g). Na and $\mathrm{O}$ peaks were present in the EDS analysis of AcAl surfaces (Table 3) suggesting the presence of sodium phases together with the oxide layers. For the AnH treatment, the modified surfaces showed a regular hierarchical structure consisting of micro-scale features (micro-pits) and regularly ordered nano-scale features (nanotubes) (Fig. 1d, h). The diameter of the nanotubes was between 25 and $35 \mathrm{~nm}$ (Fig. 1h). EDS analysis confirmed the presence of oxygen on the surface of AnH specimens (Table 3).

\subsection{Apatite forming ability}

Ca and P could be identified on the surfaces of all surface treated and as-manufactured specimens (Fig. 2, Table 4). However, there were large variations between different types of surface treatments in terms of apatite formation (Fig. 2, Table 4). Ca and P could be observed all over AcAl surfaces (Fig. 2). The largest weight percentages of $\mathrm{Ca}$ and $\mathrm{P}$ elements were seen in EDS analysis of AcAl surfaces (Table 4). Second to AcAl surfaces were AlAcH surfaces that showed slightly less frequent $\mathrm{Ca}$ and $\mathrm{P}$ contents and somewhat smaller weight percentages of Ca and P (Fig. 2, Table 4). AnH and AsM showed the lowest apatite forming ability with none to little apatite formed on the surfaces and smallest weight percentages of Ca and P (Fig. 2, Table 4).

\subsection{Cell culture assay}

In general, there were marked differences between various surface conditions in terms of cell viability and proliferation (Figs. 3-5). In terms of cell-seeding efficiency, AnH resulted in the highest cell seeding efficiency, however it was not significantly different from other surface conditions (Fig. 5a). AnH showed more homogenous distributions of cells as compared to all other surface types (Fig. 3). Cell attachment was generally not very good on AcAl surfaces, as cells were hardly observed on AcAl surfaces in the early days of culture (Fig. 4). Both AnH and AlAcH surfaces showed good cell attachments (Fig. 4). In AnH specimens, cells were more elongated and bridged the corners while they were mostly polygonal on AlAcH surfaces (Fig. 4).

Based on the measurements of the metabolic activity, AnH showed significantly higher cell proliferation as compared to AsM specimens at 4, 7, and 21 days (Fig. 5b). The other surface treatments did not have significantly better cell proliferation until 21 days at which point $\mathrm{AlAcH}$ also showed higher cell proliferation as compared to AsM specimens (Fig. 5b). Cell proliferation measured by total DNA content was consistent with the observations based on metabolic activity. AnH specimens had significantly higher DNA

Table 4

EDS analysis of the elements found on the surface of surface treated porous titanium bone substitutes after 21 days of immersion in the SBF solution.

\begin{tabular}{|c|c|c|c|c|c|c|c|c|c|c|c|}
\hline Samples & $\mathrm{C}(\% \mathrm{wt})$ & $\mathrm{O}$ (\%wt) & $\mathrm{Cu}(\% \mathrm{wt})$ & $\mathrm{Na}(\% \mathrm{wt})$ & $\mathrm{Al}(\% \mathrm{wt})$ & $\mathrm{P}(\% \mathrm{wt})$ & $\mathrm{Au}(\% \mathrm{wt})$ & $\mathrm{Cl}(\% \mathrm{wt})$ & Ca (\%wt) & Ti (\%wt) & $\mathrm{Ca} / \mathrm{p}$ \\
\hline AsM & 3.04 & 18.76 & - & 1.89 & 3.09 & 1.36 & 10.06 & 2.71 & 1.28 & 57.81 & 0.94 \\
\hline $\mathrm{AlAcH}$ & 1.95 & 25.31 & 1.39 & 1.38 & 2.4 & 1.95 & 23.98 & 1.03 & 2.39 & 38.22 & 1.23 \\
\hline AcAl & 3.52 & 9.31 & 4.34 & 3.44 & 1.77 & 2.24 & 49.5 & 4.51 & 2.46 & 18.91 & 1.1 \\
\hline $\mathrm{AnH}$ & 2.45 & 24.62 & 0.77 & 1 & 1.38 & 0.94 & 21.11 & 1.89 & 1.97 & 43.87 & 2.1 \\
\hline
\end{tabular}

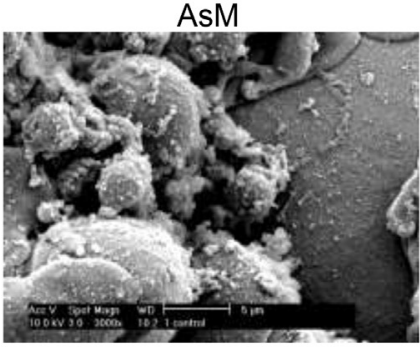

a

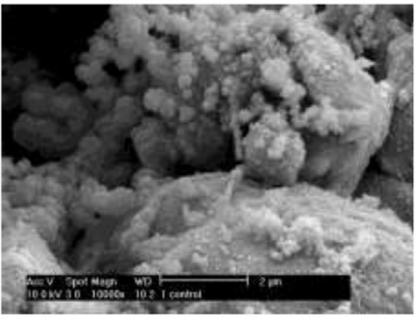

e

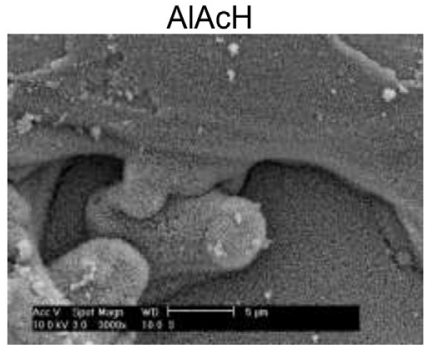

b

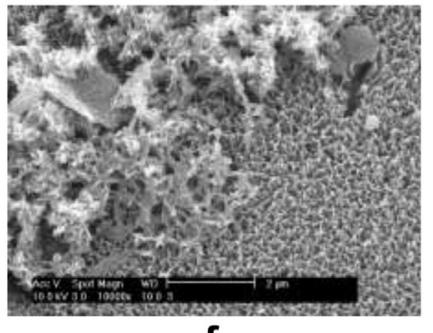

f

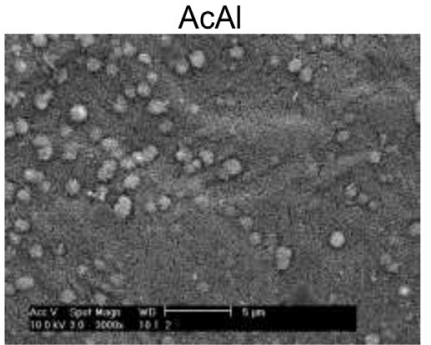

C

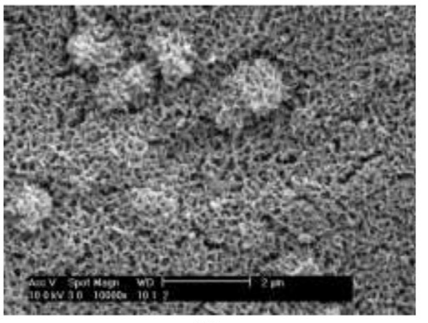

g

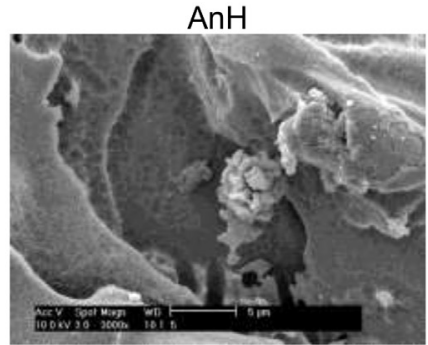

d

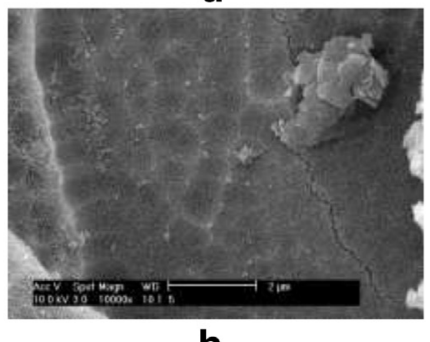

h

Fig. 2. SEM pictures of AsM (a, e), $\operatorname{AlAcH}(b, f), A c A l(c, g)$, and $A n H(d, h)$ surfaces after immersion in the SBF solution for 21 days. 


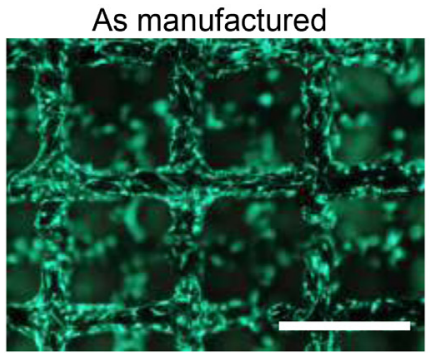

a

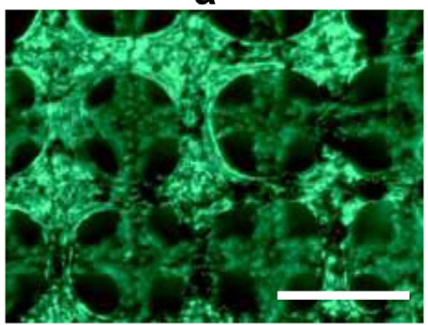

e

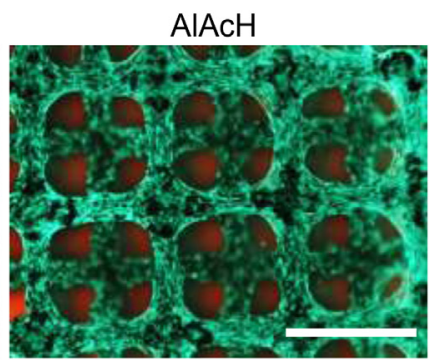

b

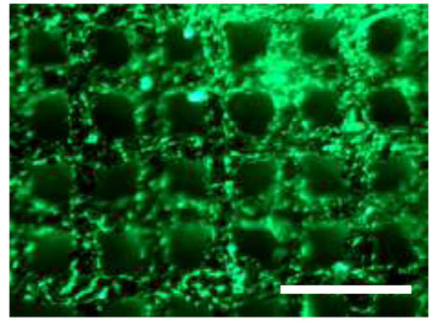

f

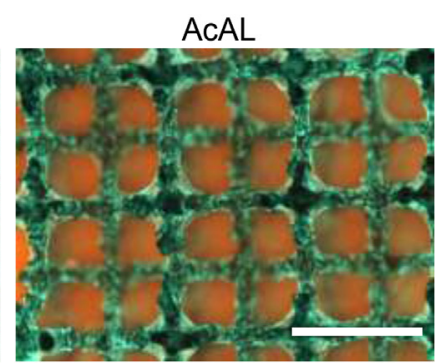

C

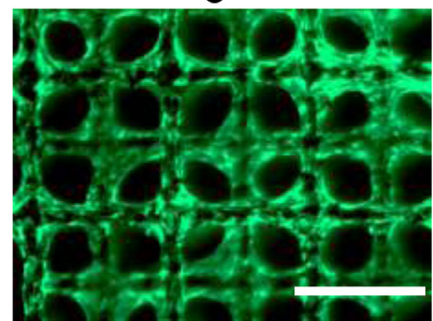

g

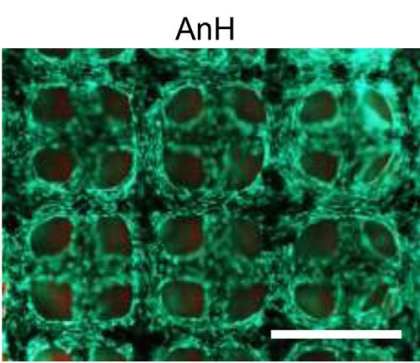

d

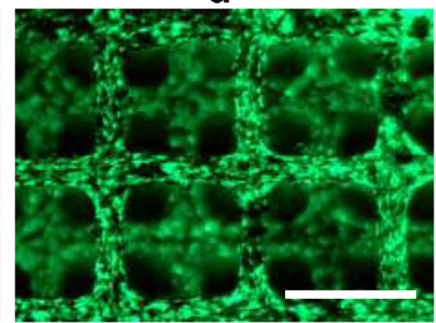

h

Fig. 3. Live-dead staining of $\operatorname{AsM}(a, e), \operatorname{AlAcH}(b, f), \operatorname{AcAl}(c, g)$, and $\operatorname{AnH}(d, h)$ surfaces after 7 and 21 days of cell culture (scale bar: $500 \mu$ m).

amounts as compared to AsM specimens both at 7 and 21 days (Fig. 5c). At 21 days, AnH specimens had significantly higher DNA amounts as compared to AcAl specimens (Fig. 5c). The other surface treatments performed similar to AsM specimens until day 21 at which point $\mathrm{AlAcH}$ specimens showed higher DNA amounts compared to both AsM and AcAl specimens (Fig. 5c). As compared to AsM specimens, AnH surfaces upregulated the expression of ALP at day 1 and VEGF at day 1 (Fig. 6). AnH surfaces also showed significantly higher expression of Col1 (day 7) and VEGF (day 1) as compared to both $\mathrm{AlAcH}$ and AcAl surfaces (Figues 6e-f). As compared to AsM surfaces, AlAcH surfaces exhibited greater expression of ALP at day 1, Runx2 at day 21, OCN at day 1, Col1 at
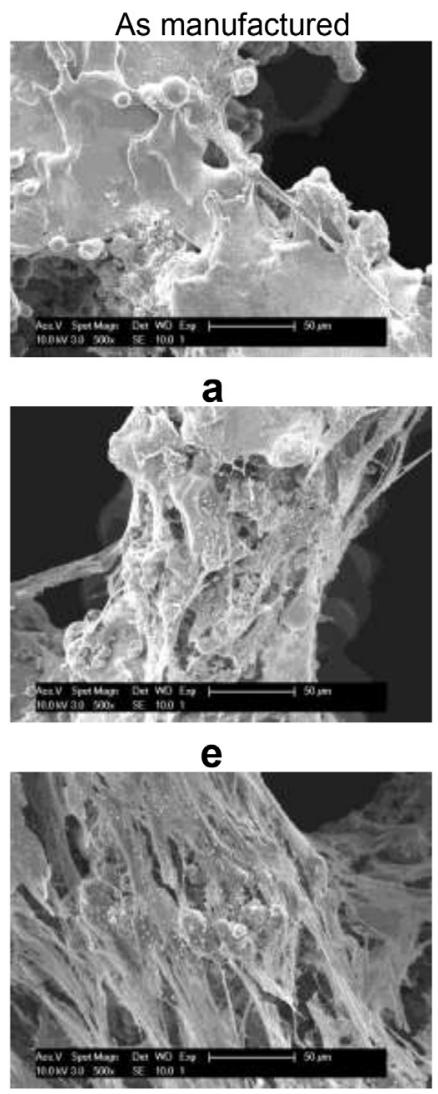

i

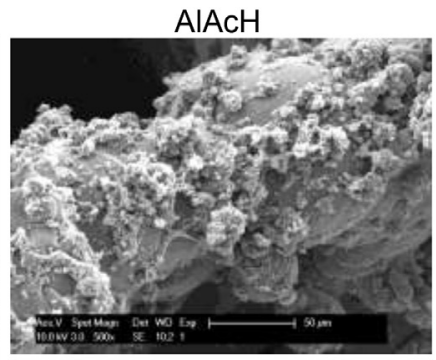

b

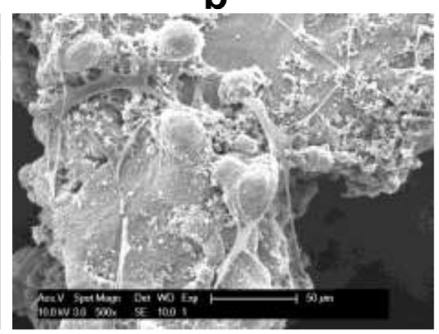

f

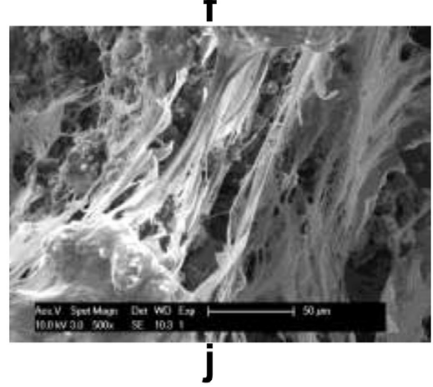

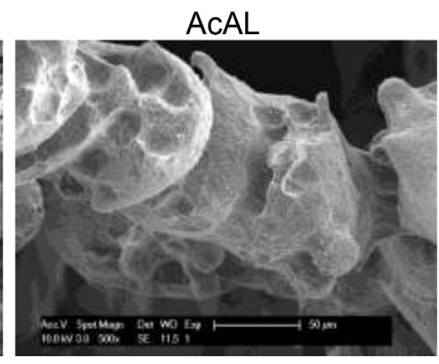

C
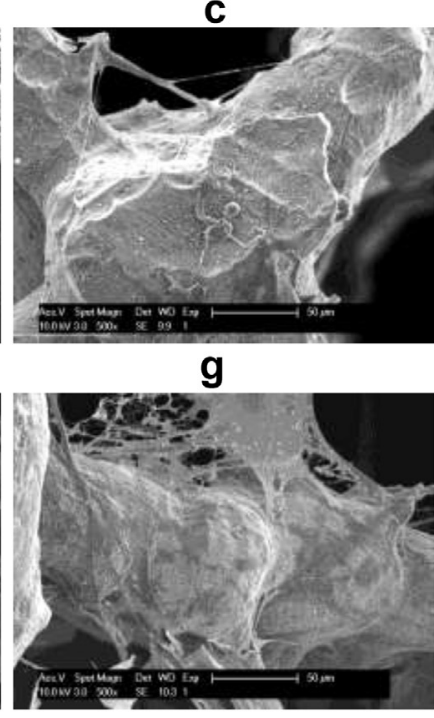

k

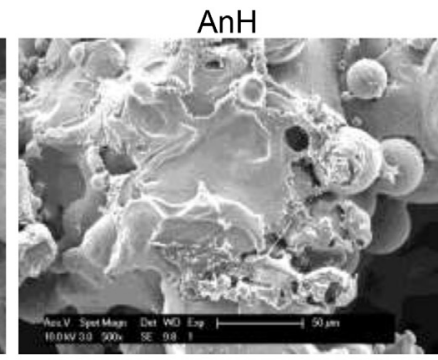

d

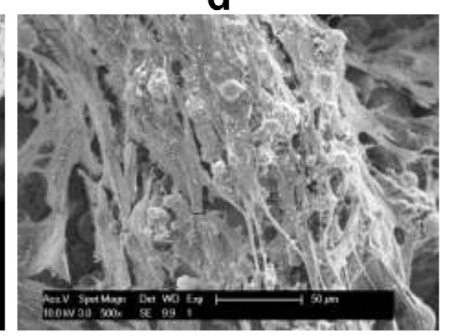

h

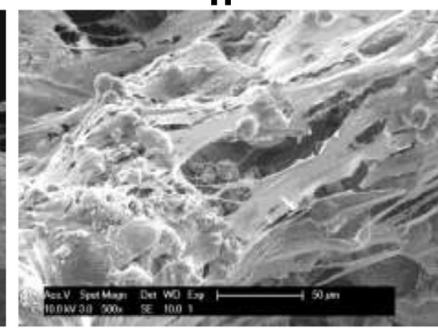

I

Fig. 4. Morphology of cells and cell attachment on AsM (a, e), AlAcH (b, f), AcAl (c, g), and AnH (d, h) surfaces after 1, 7 and 21 days of cell culture. 
a

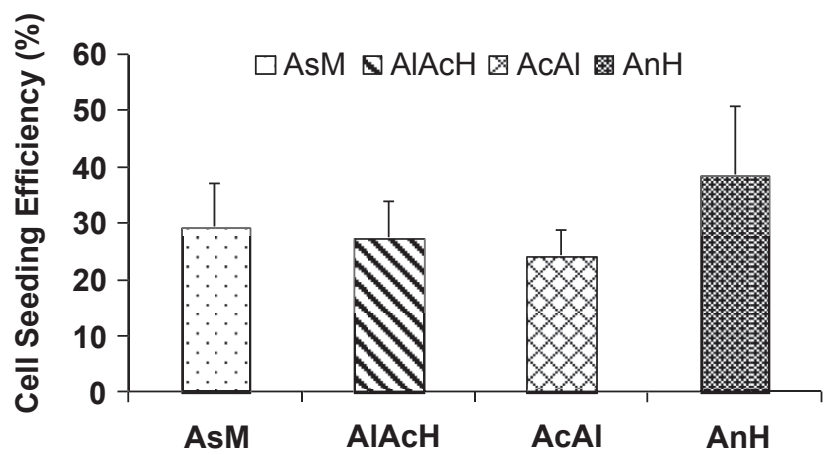

b

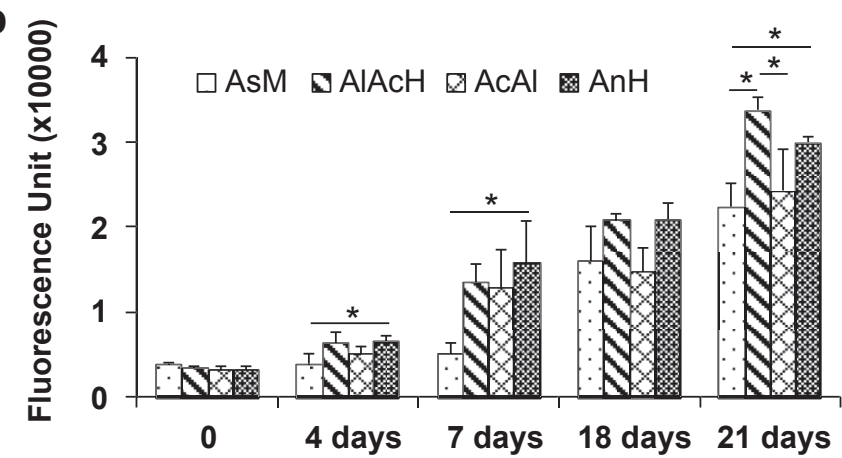

C

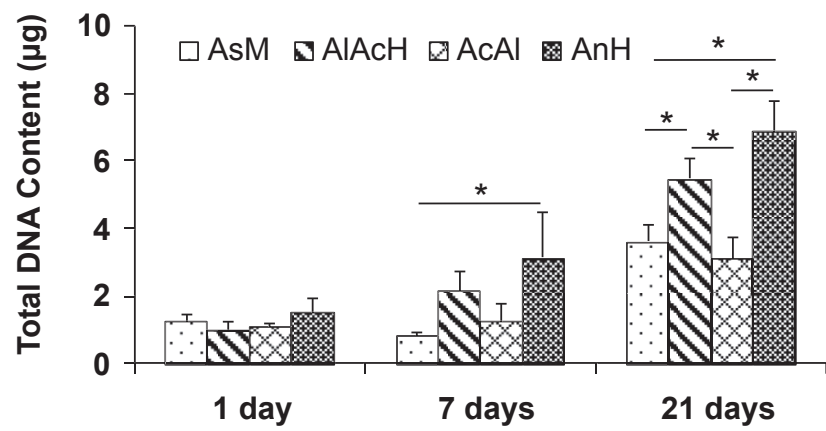

Fig. 5. Cell seeding efficiency (a) and cell proliferation measured based on metabolic activity (b) and DNA content. day 1, and VEGF at day 21 (Fig. 6). AlAcH surfaces also showed improved expression of Runx2 (day 21), OCN (day 1), Col1 (day 21), and VEGF (day 21) as compared to AcAl surfaces (Fig. 6).

\subsection{Animal experiments}

Both in vivo and ex vivo scans showed somewhat lower mean values of regenerated bone volume for the $\mathrm{AnH}$ treatment as compared to both other treatments (Figs. 7,8). However, the difference between the groups was only significant at 4 weeks, with the newly formed bone volume within the pores being significantly higher for the AcAl treatment as compared to AnH. For all later time points, there was no significant difference between the regenerated bone volumes of all three surface treatments (Figs. 7,8) neither within the pores, nor outside the pores. After 12 weeks, the differences between the gap sizes of the three groups were also nonsignificant (Fig. 8a-b). Based on two-way repeated-measures ANOVA without Bonferroni correction, when all time points were considered, the total bone regeneration (Total BV) of AcAl was significantly higher than that of $\mathrm{AnH}(p=0.03)$. However, repeatedmeasures ANOVA with or without Bonferroni correction showed no significant differences between the Total BV of AlAcH and AnH or between AlAcH and AcAl. As for the bone formed within the pores (Porous BV), both AcAl ( $p=0.015$ and 0.044 respectively without and with Bonferroni correction) and $\mathrm{AlAcH}(p=0.008$ and 0.024 respectively without and with Bonferroni correction) had significantly larger volumes of regenerated bone as compared to $\mathrm{AnH}$ when all time points were considered using two-way repeatedmeasures ANOVA.

The mean value of the maximum torque of $\mathrm{AnH}$ samples was significantly larger than that of AcAl specimens (Fig. 8c). There was no significant difference between the maximum torques of $\mathrm{AnH}$ and AlAcH specimens (Fig. 8c). Also no significant differences between the maximum rotation angles were found between the groups (Fig. 8c). Histological observations showed that the scaffold - novel bone interface mostly consisted of direct bone contact in specimens treated with AcAl (Fig. 9c, e). Both AlAcH and $\mathrm{AnH}$ specimens showed some soft tissue formation between the scaffold and the surrounding bone with AnH samples exhibiting the most limited direct bone-scaffold contact (Fig. 9a, c,d, f). The pattern of bone formation was different between the various
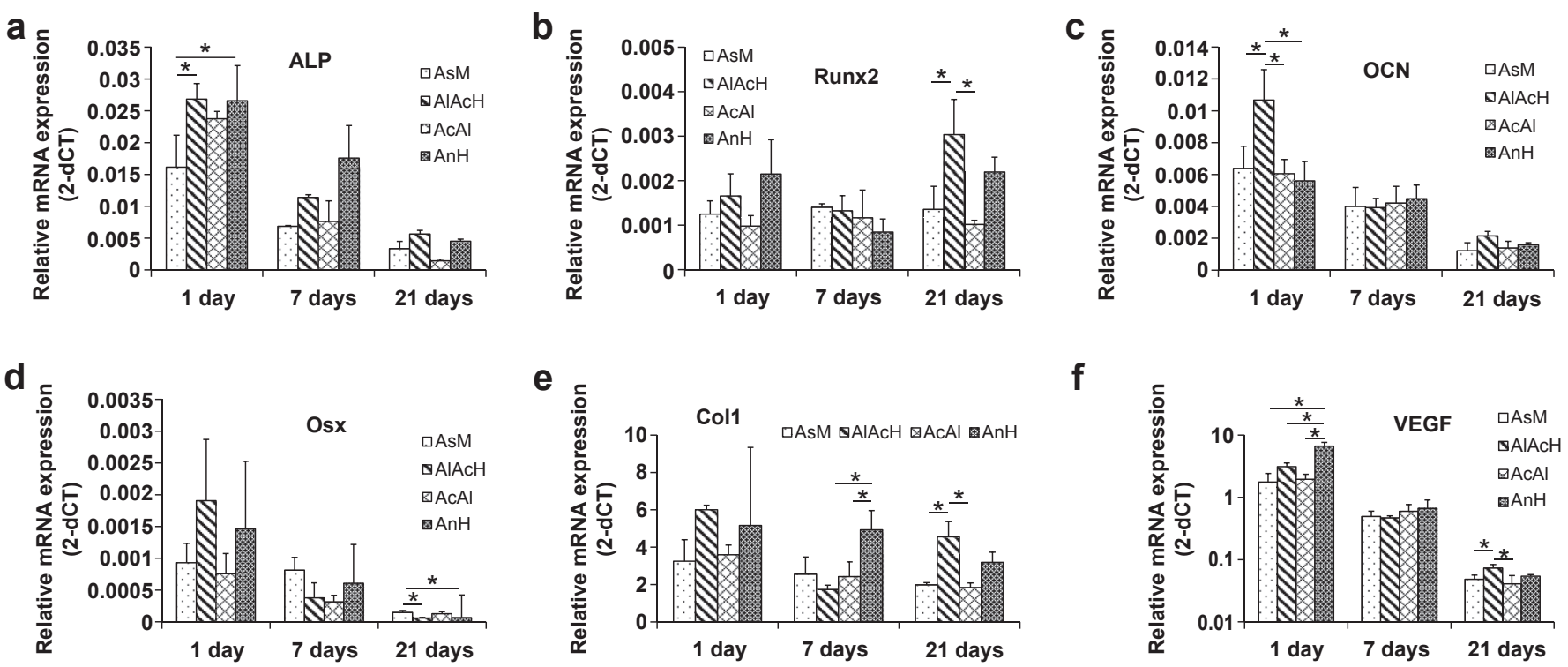

Fig. 6. Expression of ALP (a), Runx2 (b), OCN (c), Osx (d), Col1 (e), and VEGF (f) measured based on relative mRNA expression after 1, 7, and 21 days of cell culture. 
a

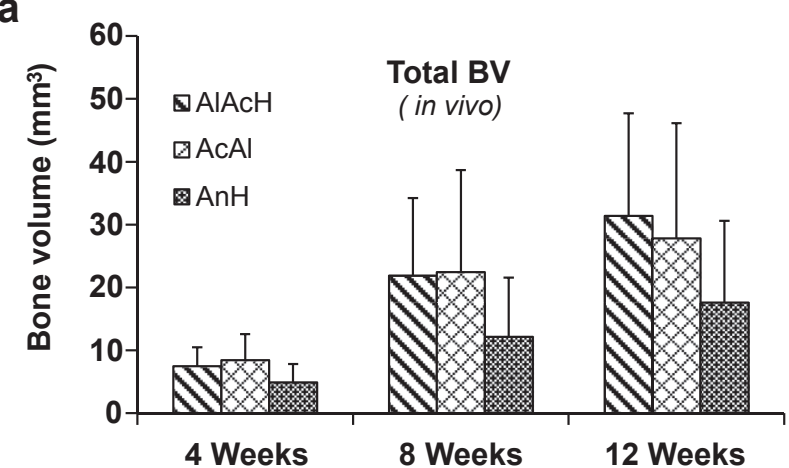

b

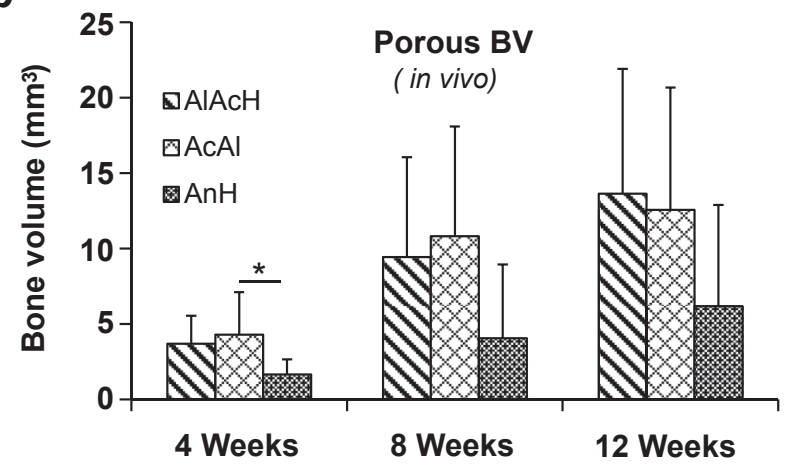

Fig. 7. Total volume of regenerated bone (Total BV) (a) and the volume of bone regenerated within the pores of the scaffold calculated based on in vivo micro-CT scans after 4,8 , and 12 weeks of surgery.

histological specimens. While the regenerated bone was strongly connected in certain specimens (e.g. Fig. 9c), some specimens exhibited abundant but loosely connected de novo bone formation (e.g. Fig. 9d-e).

\section{Discussion}

Both surface topography and chemistry were modified in the three surface treatments studied here. Results show that there are clearly different routes through which the various surface treatments function. One possible route is linked to the formation of apatite phases on the surface of the material. Apatite phases could facilitate bone formation and as such improve implant osseointegration [41,44]. The other route is interaction of cells with the nanotopography of the surface that could lead to modulation of mechanotransduction, improved cell proliferation, and stimulation of differentiation of cells towards the osteogenic lineage [45-48].

As for the apatite-forming ability, AcAl performed best with the highest amount of apatite formed on the surface of the material after the SBF test (Fig. 2, Table 4) while AnH did not form much apatite on its surface and holds no evidence that it performed any better than AsM surfaces (Fig. 2, Table 4). AlAcH is situated in between the two extremes of $\mathrm{AcAl}$ and $\mathrm{AnH}$ in terms of apatite formation (Fig. 2, Table 4). In the cell attachment, cell proliferation, and gene expression assays, $\mathrm{AnH}$ performed the best as indicated the by elongated corner-bridging cell morphology, the homogenous cell distribution, the greatest rate of cell proliferation, and the upregulated expression of osteogenic markers (Figs. 3-6). In comparison, AcAl performed poorly in the cell culture assays as underlined by its limited cell attachment and cell proliferation (Figs. 3-5). Moreover, there is not a single time point or osteogenic marker for which AcAl performed better than AsM surfaces (Fig. 6). Once more, $\mathrm{AlAcH}$ is situated between $\mathrm{AnH}$ and $\mathrm{AcAl}$ in terms of performance in the cell culture assays (Figs. 3-6).

The results of animal experiments nicely correlate with the above-mentioned in vitro findings. In terms of bone regeneration, AcAl showed a significantly higher rate of bone formation as compared to AnH. Moreover, AcAl surfaces show high levels of osseointegration as exemplified by direct bone-scaffold contact observed in the histological sections. These findings are in line with the apatite-forming ability of the surface $[41,44]$. In contrast, AnH showed significantly lower volumes of regenerated bone and did
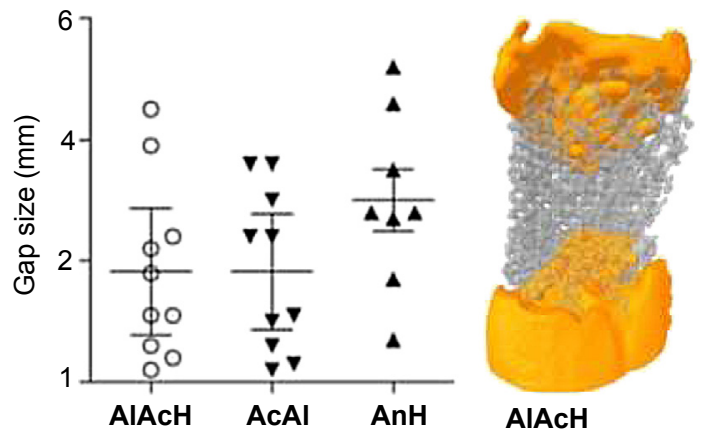

b

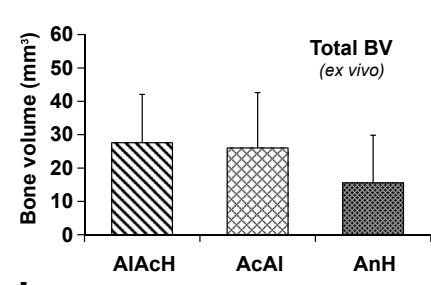

d

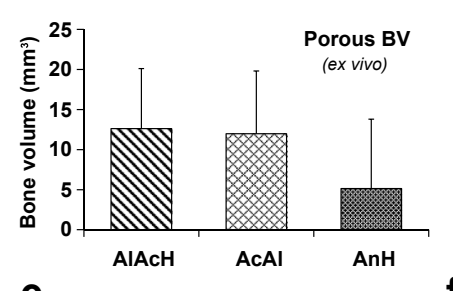

e
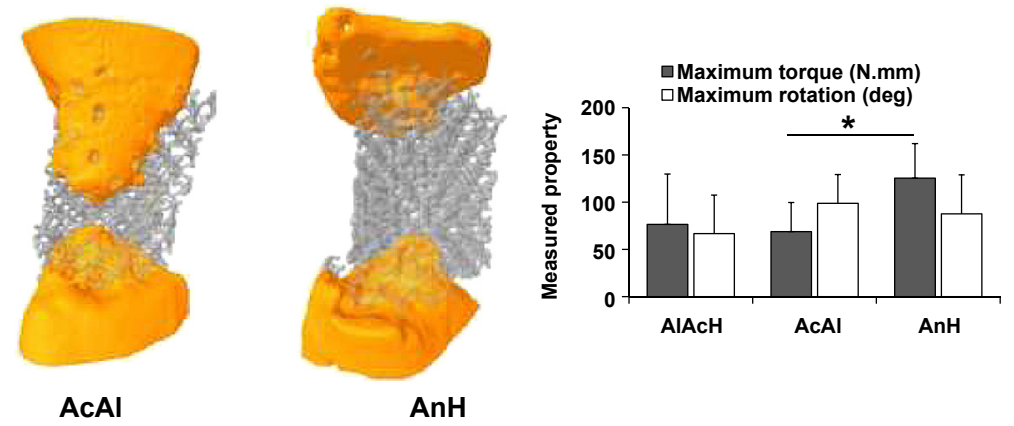

C
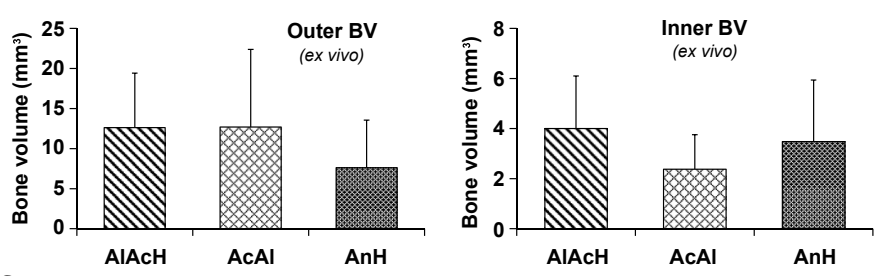

g

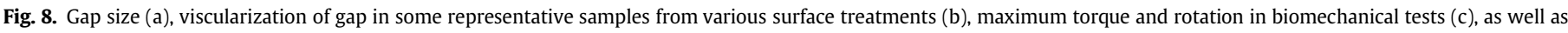
the volume of regenerated bones in different areas including Total BV (d), Porous BV (e), Outer BV (f), and Inner BV (g) calculated based on ex vivo micro-CT scans. 


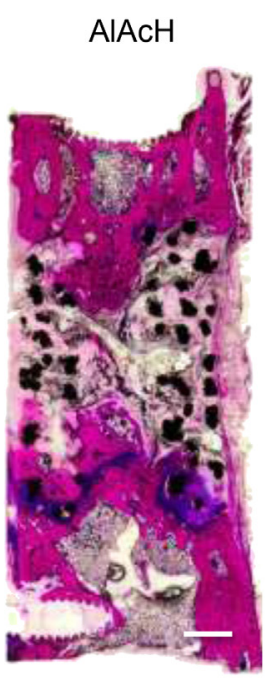

a

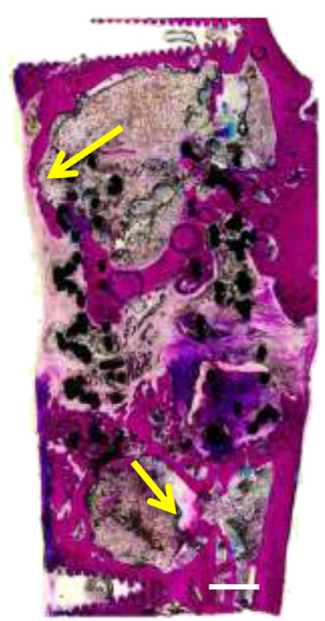

d
AcAl

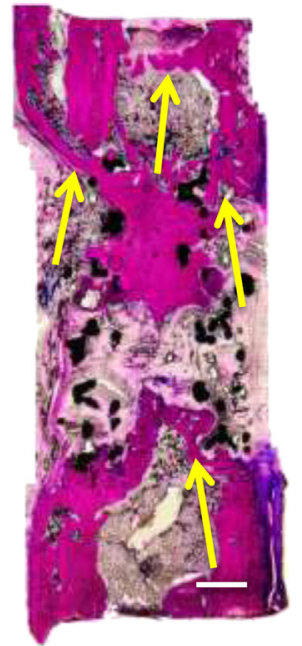

b

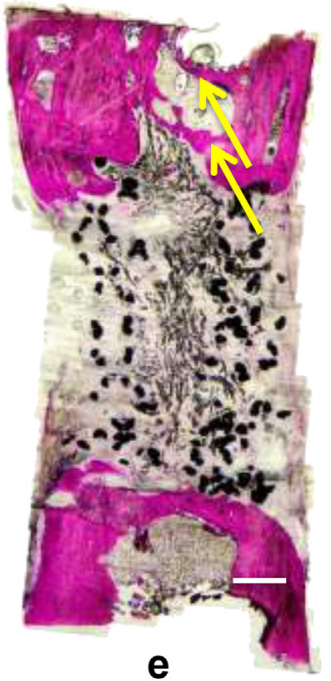

$\mathrm{AnH}$

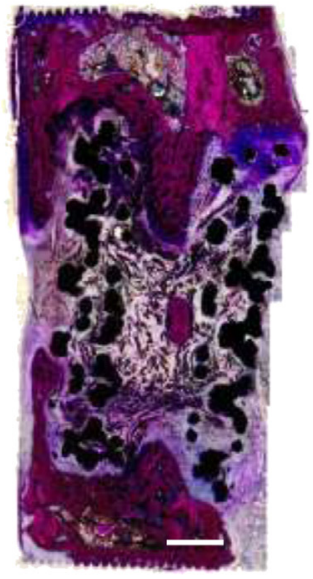

C

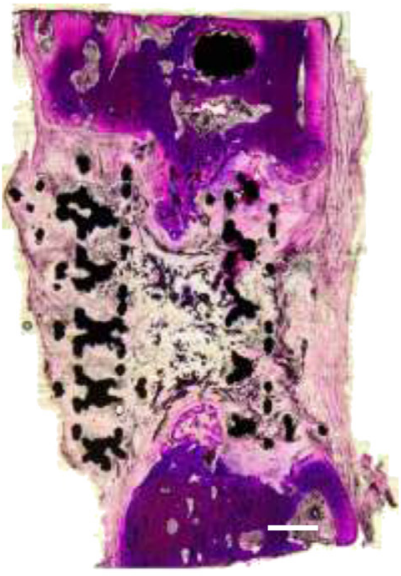

f

Fig. 9. Histological sections of $\mathrm{AlAcH}(\mathrm{a}), \mathrm{AcAl}(\mathrm{b})$, and $\mathrm{AnH}$ (c) specimens (scale bar: $1 \mathrm{~mm}$ ).

not show direct bone-scaffold contact due to soft tissue formation (Fig. 9). On the other hand, AnH showed significantly better mechanical stability as compared to AcAl (Fig. 8c). AlAcH is once more situated in between $\mathrm{AnH}$ and $\mathrm{AcAl}$ in terms of all above-mentioned measures. The AlAcH surface shows some direct bone-scaffold contact but also some formation of soft tissue (e.g. Fig. 9d). The regenerated bone volume of $\mathrm{AlAcH}$ surfaces is situated between $\mathrm{AnH}$ and AcAl. As for the maximum torque, AlAcH surfaces are again in between AnH and AcAl surfaces.

One unexpected observation is that the surface treatment that shows the largest volume of regenerated bone, i.e. AcAl, is mechanically the least stable. It is generally assumed that larger volumes of regenerated bone should necessarily translate to improved mechanical stability. It is, however, important to note that the connectivity of the regenerated bone is extremely important for load transfer and mechanical stability. Large volumes of bone that are scattered throughout the scaffold and are not well connected to each other cannot transfer mechanical load and result in a mechanically unstable construct. In comparison, a smaller volume of well-connected bone could better transfer the mechanical load and improve the mechanical stability of the bonescaffold construct. Histological observations showed formation of several packets of loosely connected bone on AcAl surfaces (see yellow annotation arrows (in web version) on Fig. 9b, e). In comparison, the bone formed in $\mathrm{AnH}$ specimens was better connected and thus more capable of transmitting mechanical loads. This could explain the significantly better mechanical stability of $\mathrm{AnH}$ specimens as compared to AcAl specimens despite their significantly lower overall volume of regenerated bone. It should be noted that the above-mentioned histological observations were made on 2D sections of only two specimens from each group. It is therefore not clear to what extent those observations are representative of the histological conditions and bone connectivity of all specimens in 3D.

It is not clear why AnH specimens might have resulted in betterconnected volumes of regenerated bone as compared to AcAl specimens. It is recently shown that nanotopography of surfaces modulates the mechanotransduction cell pathways through adjustment of focal adhesion [45-48]. It could be further hypothesized that nanotopographical features modulate mechanotransduction cell pathways with the mechanical forces transmitted through the scaffold such that the macro-scale mechanical forces guide the process of bone regeneration. If such a modulation exists, the regenerated bone is expected to be well connected and better 
capable of transmitting mechanical forces than is normally the case in the mechanically guided process of bone apposition [49,50]. This hypothesis needs to be tested in future studies to see whether nanotopographical features could indeed guide the process of bone regeneration such that the regenerated bone is capable of withstanding higher mechanical loads.

Another possible explanation for the better mechanical stability of AnH as compared to AcAl specimens could be the better interface connection between the regenerated bone tissue and scaffold in AnH specimens. Nanotopographical features might result in better (mechanical) interlocking of the regenerated tissue with the implanted biomaterial and thereby strengthen the interface between the regenerated bone and the titanium. Even though this is a plausible hypothesis, there is no experimental evidence in the current study to support it. Further studies are needed to test the hypothesis that 'as compared to surfaces with good apatite forming ability, surfaces covered with regular nanotopographical features result in greater interface strength between the regenerated bone tissue and implanted biomaterial'.

\section{Conclusions}

The results of the current longitudinal study show that all the surface treatments studied here could achieve one or more of the aims mentioned in the introduction including generation of a hierarchical structure of ordered micro- and nanotopographical features, improved cell response, and improved apatite-forming ability. The applied surface treatments were found to act through different mechanisms. AcAl improved apatite forming ability while it did not influence the in vitro cell response of the biomaterial. In contrast, AnH significantly improved the in vitro cell response of the biomaterial without having any influence on its apatite forming ability. As far as clinical applications are concerned, the mechanical stability plays the most important role. AnH resulted in significantly better mechanical stability as compared to AcAl even though its volume of regenerated bone was significantly smaller than AcAl. It could be therefore concluded that large volumes of regenerated bone do not necessarily translate to better mechanical stability or higher fracture load. In conclusion, the applied surface treatments are found to markedly influence both in vitro and in vivo performances of porous titanium alloy biomaterials. The surface treatments of porous titanium biomaterials should therefore be thoroughly studied and carefully optimized prior to clinical application.

\section{Acknowledgments}

This research forms part of the Project P2.04 BONE-IP of the research program of the BioMedical Materials institute, co-funded by the Dutch Ministry of Economic Affairs. The technical supports of Harry Jansen and Patrick van Holst for biomechanical testing is also acknowledged.

\section{References}

[1] Sen M, Miclau T. Autologous iliac crest bone graft: should it still be the gold standard for treating nonunions? Injury 2007:38:S75-80.

[2] Dimitriou R, Mataliotakis GI, Angoules AG, Kanakaris NK, Giannoudis PV. Complications following autologous bone graft harvesting from the iliac crest and using the RIA: a systematic review. Injury 2011;42:S3-15.

[3] Pelissier P, Masquelet A, Bareille R, Pelissier SM, Amedee J. Induced membranes secrete growth factors including vascular and osteoinductive factors and could stimulate bone regeneration. J Orthop Res 2004;22:73-9.

[4] Kokubo S, Mochizuki M, Fukushima S, Ito T, Nozaki K, Iwai T, et al. Long-term stability of bone tissues induced by an osteoinductive biomaterial, recombinant human bone morphogenetic protein-2 and a biodegradable carrier. Biomaterials 2004;25:1795-803.
[5] Duan B, Wang M, Zhou WY, Cheung WL, Li ZY, Lu WW. Three-dimensional nanocomposite scaffolds fabricated via selective laser sintering for bone tissue engineering. Acta Biomater 2010;6:4495-505.

[6] Goodridge R, Dalgarno K, Wood D. Indirect selective laser sintering of an apatite-mullite glass-ceramic for potential use in bone replacement applications. Proc Inst Mech Eng H 2006;220:57-68.

[7] Simpson RL, Wiria FE, Amis AA, Chua CK, Leong KF, Hansen UN, et al. Development of a 95/5 poly (L-lactide-co-glycolide)/hydroxylapatite and $\beta$-tricalcium phosphate scaffold as bone replacement material via selective laser sintering. J Biomed Mater Res B Appl Biomater 2008;84:17-25.

[8] Williams JM, Adewunmi A, Schek RM, Flanagan CL, Krebsbach PH, Feinberg SE et al. Bone tissue engineering using polycaprolactone scaffolds fabricated via selective laser sintering. Biomaterials 2005;26:4817-27.

[9] Mullen L, Stamp RC, Brooks WK, Jones E, Sutcliffe CJ. Selective laser melting: a regular unit cell approach for the manufacture of porous, titanium, bone ingrowth constructs, suitable for orthopedic applications. J Biomed Mater Res B Appl Biomater 2009;89:325-34.

[10] Pattanayak DK, Fukuda A, Matsushita T, Takemoto M, Fujibayashi S, Sasaki K, et al. Bioactive Ti metal analogous to human cancellous bone: fabrication by selective laser melting and chemical treatments. Acta Biomater 2011;7: 1398-406.

[11] Vandenbroucke B, Kruth J-P. Selective laser melting of biocompatible metals for rapid manufacturing of medical parts. Rapid Prototyp J 2007; 13:196-203.

[12] Warnke PH, Douglas T, Wollny P, Sherry E, Steiner M, Galonska S, et al. Rapid prototyping: porous titanium alloy scaffolds produced by selective laser melting for bone tissue engineering. Tissue Eng Part C Methods 2008;15: $115-24$.

[13] Lin CY, Wirtz T, LaMarca F, Hollister SJ. Structural and mechanical evaluations of a topology optimized titanium interbody fusion cage fabricated by selective laser melting process. J Biomed Mater Res A 2007:83:272-9.

[14] Murphy CM, Haugh MG, O'Brien FJ. The effect of mean pore size on cell attachment, proliferation and migration in collagen-glycosaminoglycan scaffolds for bone tissue engineering. Biomaterials 2010;31:461-6.

[15] Campoli G, Borleffs MS, Amin Yavari S, Wauthle R, Weinans H, Zadpoor AA Mechanical properties of open-cell metallic biomaterials manufactured using additive manufacturing. Mater Des 2013;49:957-65.

[16] van der Stok J, Wang H, Amin Yavari S, Siebelt M, Sandker M, Waarsing JH, et al. Enhanced bone regeneration of cortical segmental bone defects using porous titanium scaffolds incorporated with colloidal gelatin gels for time and dose controlled delivery of dual growth factors. Tissue Eng Part A 2013;19: 2605-14.

[17] Jonášová L, Müller FA, Helebrant A, Strnad J, Greil P. Biomimetic apatite formation on chemically treated titanium. Biomaterials 2004;25:1187-94.

[18] Nebe JB, Müller L, Lüthen F, Ewald A, Bergemann C, Conforto E, et al. Osteoblast response to biomimetically altered titanium surfaces. Acta Biomater 2008;4:1985-95.

[19] Amin Yavari S, Wauthle R, Böttger AJ, Schrooten J, Weinans H, Zadpoor AA Crystal structure and nanotopographical features on the surface of heattreated and anodized porous titanium biomaterials produced using selective laser melting. Appl Surf Sci 2014;290:287-94.

[20] Arima Y, Iwata $\mathrm{H}$. Effect of wettability and surface functional groups on protein adsorption and cell adhesion using well-defined mixed self-assembled monolayers. Biomaterials 2007;28:3074-82.

[21] Kokubo T. Surface chemistry of bioactive glass-ceramics. J Non-cryst Solids 1990:120:138-51.

[22] Zreiqat H, Valenzuela SM, Nissan BB, Roest R, Knabe C, Radlanski RJ, et al. The effect of surface chemistry modification of titanium alloy on signalling pathways in human osteoblasts. Biomaterials 2005;26:7579-86.

[23] Beşkardeş IG, Gümüșderelioğlu M. Biomimetic apatite-coated PCL scaffolds: effect of surface nanotopography on cellular functions. J Bioact Compat Polym 2009;24:507-24.

[24] Kim M-J, Lee B, Yang K, Park J, Jeon S, Um SH, et al. BMP-2 peptidefunctionalized nanopatterned substrates for enhanced osteogenic differentiation of human mesenchymal stem cells. Biomaterials 2013;34:7236-46.

[25] Neoh KG, Hu X, Zheng D, Kang ET. Balancing osteoblast functions and bacterial adhesion on functionalized titanium surfaces. Biomaterials 2012;33: 2813-22.

[26] Patel S, Kurpinski K, Quigley R, Gao H, Hsiao BS, Poo M-M, et al. Bioactive nanofibers: synergistic effects of nanotopography and chemical signaling on cell guidance. Nano Lett 2007;7:2122-8.

[27] Zhang W, Wang G, Liu Y, Zhao X, Zou D, Zhu C, et al. The synergistic effect of hierarchical micro/nano-topography and bioactive ions for enhanced osseointegration. Biomaterials 2013:34:3184-95.

[28] Nishiguchi S, Kato H, Neo M, Oka M, Kim H-M, Kokubo T, et al. Alkali- and heat-treated porous titanium for orthopedic implants. J Biomed Mater Res 2001;54:198-208.

[29] Fukuda A, Takemoto M, Saito T, Fujibayashi S, Neo M, Pattanayak DK, et al. Osteoinduction of porous Ti implants with a channel structure fabricated by selective laser melting. Acta Biomater 2011;7:2327-36.

[30] Pattanayak D, Yamaguchi S, Matsushita T, Kokubo T. Nanostructured positively charged bioactive $\mathrm{TiO}_{2}$ layer formed on Ti metal by $\mathrm{NaOH}$, acid and heat treatments. J Mater Sci Mater Med 2011;22:1803-12.

[31] Li X, Wang C, Wang L, Zhang W, Li Y. Fabrication of bioactive titanium with controlled porous structure and cell culture in vitro. Rare Metal Mat Eng 2010;39:1697-701. 
[32] Takemoto M, Fujibayashi S, Neo M, Suzuki J, Matsushita T, Kokubo T, et al. Osteoinductive porous titanium implants: effect of sodium removal by dilute $\mathrm{HCl}$ treatment. Biomaterials 2006;27:2682-91.

[33] Chen Y, Feng B, Zhu Y, Weng J, Wang J, Lu X. Preparation and characterization of a novel porous titanium scaffold with 3D hierarchical porous structures. J Mater Sci Mater Med 2011;22:839-44.

[34] Zhang Q, Leng Y, Xin R. A comparative study of electrochemical deposition and biomimetic deposition of calcium phosphate on porous titanium. Biomaterials 2005;26:2857-65.

[35] Zhao C, Zhu X, Liang K, Ding J, Xiang Z, Fan H, et al. Osteoinduction of porous titanium: a comparative study between acid-alkali and chemical-thermal treatments. J Biomed Mater Res B Appl Biomater 2010;95B:387-96.

[36] Das K, Bose S, Bandyopadhyay A. Surface modifications and cell-materials interactions with anodized Ti. Acta Biomater 2007;3:573-85.

[37] George E, Yao C, Webster TJ. Enhanced osteoblast adhesion to drug-coated anodized nanotubular titanium surfaces. Int J Nanomed 2008·3·257-64.

[38] Minagar S, Wang J, Berndt CC, Ivanova EP, Wen C. Cell response of anodized nanotubes on titanium and titanium alloys. J Biomed Mater Res A 2013;101: 2726-39.

[39] Yao C, Slamovich EB, Webster TJ. Enhanced osteoblast functions on anodized titanium with nanotube-like structures. J Biomed Mater Res A 2008;85A: $157-66$.

[40] Amin Yavari S, Wauthle R, van der Stok J, Riemslag AC, Janssen M, Mulier M, et al. Fatigue behavior of porous biomaterials manufactured using selective laser melting. Mater Sci Eng C Mater Biol Appl 2013;33:4849-58.
[41] Kokubo T, Takadama H. How useful is SBF in predicting in vivo bone bioactivity? Biomaterials 2006;27:2907-15.

[42] Chai YC, Roberts SJ, Van Bael S, Chen Y, Luyten FP, Schrooten J. Multi-level factorial analysis of $\mathrm{Ca} 2+/ \mathrm{Pi}$ supplementation as bio-instructive media for in vitro biomimetic engineering of three-dimensional osteogenic hybrids. Tissue Eng Part C Methods 2011;18:90-103.

[43] Van der Stok J, Van der Jagt O, Amin Yavari S, De Haas M, Waarsing J, Jahr H, et al. Selective laser melting-produced porous titanium scaffolds regenerate bone in critical size cortical bone defects. J Orthop Res 2013:31:792-9.

[44] Ducheyne P, Qiu Q. Bioactive ceramics: the effect of surface reactivity on bone formation and bone cell function. Biomaterials 1999;20:2287-303.

[45] Kim HN, Jiao A, Hwang NS, Kim MS, Kang DH, Kim D-H, et al. Nanotopography-guided tissue engineering and regenerative medicine. Adv Drug Deliv Rev 2013;65:536-58.

[46] Kulangara K, Yang Y, Yang J, Leong KW. Nanotopography as modulator of human mesenchymal stem cell function. Biomaterials 2012:33:4998-5003.

[47] McNamara LE, McMurray RJ, Biggs MJ, Kantawong F, Oreffo RO, Dalby MJ. Nanotopographical control of stem cell differentiation. J Tissue Eng 2010;1: 120623.

[48] Sun Y, Chen CS, Fu J. Forcing stem cells to behave: a biophysical perspective of the cellular microenvironment. Annu Rev Biophys 2012;41:519-42.

[49] Campoli G, Weinans H, Zadpoor AA. Computational load estimation of the femur. J Mech Behav Biomed Mater 2012;10:108-19.

[50] Zadpoor AA, Campoli G, Weinans H. Neural network prediction of load from the morphology of trabecular bone. Appl Math Model 2013;37:5260-76. 